\title{
The use of conjoint analysis to determine consumer buying preferences: A literature review
}

\author{
Ernest North and Retha de Vos
}

\begin{abstract}
OPSOMMING
Akademiese navorsers en praktisyns verskil wanneer dit by die klassifikasie, waarde en gebruike van eksperimente as ' $n$ bron van primêre data kom. ' $n$ Eksperimentele ontwerp word as een van vier voorwaardes vir ' $n$ kousale navorsingsontwerp beskou. Die eksperiment kan verskeie vorme aanneem, en in die veld of in 'n laboratorium uitgevoer word. Sommige navorsers beskou voorkeurkeuse ontleding (conjoint analysis) as ' $n$ spesiale tipe eksperiment wat normaalweg in ' $n$ laboratorium plaasvind.
\end{abstract}

As 'n navorsingsmetode behels voorkeurkeuse ontleding in wese dat die utiliteitswaarde wat verbruikers aan sekere vlakke of kombinasies van die eienskappe van produkte en dienste toeken, afgelei word. Navorsers en bemarkers kan deur middel van so ' $n$ voorkeurkeuse studie byvoorbeeld ' $n$ beter begrip ontwikkel van die werklike waarde wat verbruikers aan produkeienskappe heg wanneer aankoopbesluite geneem moet word.

Die primêre doel van die artikel is om 'n teoretiese oorsig van die aard van voorkeurkeuse ontleding as 'n navorsingsmetode te gee, en die waarde wat dit vir navorsers in die bemarkings - en verbruikerswetenskapvelde inhou, toe te lig. Onlangse studies sal vermeld word, en die proses om 'n voorkeurkeuse ontleding te onderneem, sal aandag geniet.

\section{- Prof EJ North}

Department of Marketing and Communication Management, University of Pretoria

- Ms R de Vos

Commercial Methods \& Training Manager Peugeot Motors South Africa

\section{INTRODUCTION}

A review of the marketing research literature indicates that academic researchers and practitioners have different viewpoints with respect to the classification, value, and use of experiments as a source of primary data (Cooper \& Schindler, 1998:381; Dane, 1990:88; Peter \& Donnelly, 2001:37; and Bearden et al, 2001:127). Cooper and Schindler (1998:130), for example, use eight different descriptors to classify a research design. One of these is the power of the researcher to manipulate the variables, in which case two kinds of design can be used, namely experimental and post facto. Burns and Bush (1998:111, 119-128) refer to an experimental design as one of four formal conditions for a causal research design. These authors state that causality "... may be thought of as understanding a phenomenon in terms of conditional statements of the form 'If $x$, then $y$ "' (Burns \& Bush, 1998:119). Churchill and lacobucci (2002:91) also describe a causal research design as one that is concerned with cause-and-effect relationships. Studies of this kind normally take the form of experiments, because they are best suited to determining cause and effect. Sudman and Blair (1998:207) group experiments as one of the three major sources of primary data (the other two being surveys, and focus groups and depth interviews).

According to Sudman and Blair (1998:207), there are no standard rules when a researcher decides to conduct an experiment. The experiment can take many different forms and can be conducted in a laboratory or in the field. In a field study any phenomenon of interest or any research topic is studied in a natural setting. The laboratory experiment, on the other hand, studies the phenomenon outside the natural setting. The term "laboratory" refers to any context other than the natural setting (such as supermarkets, malls and retail stores). In a laboratory experiment the researcher creates a desired condition where one or more causal variables are manipulated, and the effect of this manipulation on one or more dependent variables is measured. For example, a magazine company printed various cover designs and asked the employees in its offices to indicate the design they liked best (Sudman \& Blair, 1998:206). Considered by Sudman and Blair (1998:229) to be a special type of experiment, conjoint analysis is mostly applied in a laboratory situation.

\section{AIM OF THE ARTICLE}

Conjoint analysis has been used in research for many years (Green \& Sprinivasan, 1978). Hair et al 
(1998:388) state that the application of conjoint analysis in the United States has been paralleled in other parts of the world as well as in Europe. However, it appears to have only recently attracted the attention of local researchers and it is not clear why local academic researchers in particular do not make more use of conjoint analysis.

The main aim of this article is to provide an overview of the nature and use of conjoint analysis as a research tool, and to indicate its value when, for example, a researcher wishes to analyse female consumers' apparel purchasing decisions based on the value they attach to certain attributes when making a purchasing decision. Although the apparel industry has reached maturity and growth is very slow, fashion trend cycles are accelerating. The presence of more and more brands has created a competitive environment unheard-of in the past (Rutter \& Edwards, 1999:31).

Past research mostly used survey methods that directly measure consumers' attitudes towards products and their attributes. According to Lang and Crown (1993), the possibility of interaction effects among attributes is usually overlooked. The preferences of female consumers for apparel items may depend on the joint influence of product attributes such as quality, style and price. Thus, the joint effect of several product attributes on the final decision to purchase a specific item of clothing should be taken into consideration when researching consumer purchasing decisions.

De Vos (2002) therefore lists the following reasons why researchers, and local apparel manufacturers and retailers, for example, could use the information from a conjoint study:

- to gain a better understanding of consumers' selection criteria when purchasing apparel

- to plan their apparel merchandise mixes more efficiently

- to plan their promotional messages and strategies more effectively,

- to refine their training strategies for sales consultants.

The article will also refer to recent South African studies that have been done in this field, and special attention will be given to the process of designing a conjoint analysis experiment.

\section{THE NATURE OF CONJOINT ANALYSIS}

\section{Description}

Attempts to construct consumer typologies are an enduring feature of retailing research and frequently centre on economic and demographic characteristics. Such research highlights the relatively poor understanding of real-life consumer behaviour and, in particular, the need to develop more appropriate methods of examining the behaviour of consumers in real-life retail settings. By using a conjoint study researchers could gain a better understanding of the real value consumers attach to certain attributes when making purchasing decisions in a retail situation.

The concept conjoint analysis is described by Hair et al (1998:392) as follows: "Conjoint analysis is a multivariate technique used specifically to understand how respondents develop preferences for products or services. It is based on the simple premise that consumers evaluate the value of a product or service by combining the separate amounts of value provided by each attribute." Sudman and Blair (1998:229-230) warn that it is not a data analysis procedure like factor analysis or cluster analysis. It must be regarded as a type of "thought experiment" designed to show how various elements of products or services (price, brand, style) predict customer preferences for a product or service. Kotler (2000:339) defines conjoint analysis as "...a method for deriving the utility values that consumers attach to varying levels of a product's attributes." Churchill and lacobucci (2002:748) refer to conjoint analysis as "...conjoint measurement, which relies on the ability of respondents to make judgments about stimuli." These stimuli represent some predetermined combinations of attributes, and during a laboratory experiment, respondents are asked to make judgments about their preferences for various attribute combinations. The basic aim, therefore, is to determine the features they most prefer. From the definitions given above it is clear that conjoint studies centre around certain attributes of products or services and also various levels within each attribute. Table 1 below summarises a hypothetical situation in relation to prospective female apparel buyers, indicating some attributes and the levels that might be considered during the process of deciding to purchase a white shirt for everyday wear.

In a real-life situation respondents may find it difficult to indicate which attributes they considered and also how they combined them to form their overall opinion. The value of conjoint analysis lies in the fact that it estimates how much each of these attributes is valued, and as Churchill and lacobucci (2002:748) state, "...the word conjoint has to do with the notion that the relative values of things considered jointly can be measured when they might not be measurable if taken one at a time." From the information given in

TABLE 1: ATTRIBUTES CONSIDERED BY PROSPECTIVE APPAREL BUYERS

\begin{tabular}{|l|l|}
\hline ATTRIBUTES & LEVELS \\
\hline Price & R90 \\
& R170 \\
& R350 \\
\hline Brand & Designer \\
& Private label \\
& Unbranded \\
\hline Style & High fashion \\
& Classical \\
& Comfortable \\
\hline
\end{tabular}


Table 1 a reasonable assumption would be that many buyers would probably prefer the cheaper to mediumpriced private label shirt that is comfortable. This may, however, not necessarily always be the case because the premium priced shirt might be more comfortable owing to excellent design and craftsmanship. Prospective buyers may therefore find it necessary to trade off some of one feature to secure more of another. The key question then, is to determine how the buyers value these specific attributes. For example, is low price valued more highly, or are the consumers willing to pay a higher price to secure some of the other features. In the shirt example, the respondents are asked to rank the descriptions or attributes in order of preference. Thus, the shirt description can be constructed by using all 27 possible combinations of the attributes as follows: three dimensions, with three levels each $(3 \times 3 \times 3=27)$. Each combination is then written on a separate card. The following are some examples of such cards:

\section{Price R170 \\ Designer brand \\ Classical style}

Another card can look as follows:

$$
\begin{aligned}
& \text { Private label } \\
& \text { Comfortable style } \\
& \text { Price R350 }
\end{aligned}
$$

The 27 cards are then arranged in random order, and the respondents are asked to rearrange and rank the cards from least preferred to most preferred. The mean rankings for the various levels (for example Price: R90 vs R170 vs R350) are determined and the respondents' utilities for the attributes are then calculated with the aid of sophisticated computer programs such as Conjoint Value Analysis (CVA) Version 2.0. A summary outlining the nature and use of conjoint analysis is given in Table 2 .

\section{The value of conjoint analysis in research}

In conjoint analysis respondents indicate their preference for a series of hypothetical multi-attribute alternatives, which are typically displayed as profiles of attributes. The responses to these profiles are analysed to yield estimates of the relative importance of the attributes and to build predictive models of consumer choice for new alternatives (Oppewal \& Vriens, 2000). Conjoint analysis is a dependence technique that has brought new sophistication to the evaluation of objects, such as new products, services or ideas (Hair et al, 1998:15). The theory and methods of conjoint analysis deal with complex decision-making, or the process of assessment, comparison, and/or evaluation. In this process consumers decide which aspects of products or services are important, compare the products or services on each of the important aspects, and decide which one to choose (Louviere, 1988:9).

Schutte (1999:90-92) lists the following to indicate the value of conjoint analysis in assisting marketers to provide answers when strategic marketing and selling decisions have to be made:

\section{Understanding market preferences When a} product has, say five key attributes: price, quality, style, brand and packaging, these attributes and their associated levels represent the factors that materially affect consumer preferences.

Predicting market choices Conjoint analysis offers the researcher opportunities to apply certain simulations. The simulation capability of conjoint analysis enables the analyst to explore alternative market scenarios. The impact on market share or changes in the product can be assessed and the impact of competitive moves can then be anticipated (Wyner, 1995).

Developing market strategies It can aid marketers to identify product concepts that are extremely attractive from the consumer's perspective. Concepts that are not technically or financially feasible can be eliminated. The best of the remaining products must be selected, and then the attributes of this product must be fine-tuned to achieve the stated objective. A series of simulation tests must be run to identify the point at which the product performs best (Wyner, 1995).

Segmenting the market Conjoint results are very useful for segmentation purposes. Consumers may be segmented on the basis of utility values or attribute important scores. Thus simulations can be viewed as segmentation analyses that group people together according to their most preferred product among other substitutes or competitive products (Wyner, 1995).

TABLE 2: $\quad$ SUMMARY OF CONJOINT ANALYSIS

\begin{tabular}{|l|l|l|}
\hline Technique & What it does & What it is used for \\
\hline Conjoint Analysis & $\begin{array}{l}\text { Allows consumer preferences for a } \\
\text { product or service to be broken down } \\
\text { into trade-offs among its individual at- } \\
\text { tributes, without separating those attrib- } \\
\text { utes from the context in which overall } \\
\text { judgments are made. }\end{array}$ & $\begin{array}{l}\text { Optimising product configurations; } \\
\text { studying price elasticities of de- } \\
\text { mand; simulating market response } \\
\text { to new or modified offerings; diag- } \\
\text { nosing competitive strengths and } \\
\text { weaknesses }\end{array}$ \\
\hline
\end{tabular}

(Adapted from Market Decisions Corporation, 1996.) 
The information gained from a conjoint study could also be used for the development of a theoretical model towards understanding consumer apparel purchasing decisions. There seems to be a lack in marketing theory when it comes to explaining what is important to consumers concerning apparel purchasing decisions, as well as how they make trade-offs between various product attributes when purchasing apparel. According to Sheth and Sisodia (1999) market-centric concepts are essential and have been fundamental in devising marketing strategies. However, it is no longer sufficient to segment a market based on demographics, socio-economic class, and other segmentation variables only. Today, the marketplace is characterised by higher levels of diversity. Therefore, it would be more appropriate to use a construct such as attribute importance as a basis for segmentation. The results of a scientific conjoint study could therefore be used as a basis for segmenting the women's everyday wear apparel market. A few recent conjoint studies undertaken in South Africa are described below.

\section{Application of conjoint measurement studies in South Africa}

Schutte (1999) carried out research in the latter half of the previous decade to determine the role of price sensitivity in the demand for accommodation by local visitors to the Kruger National Park. The research problem stemmed from the fact that the Kruger National Park had experienced a decline in the demand for accommodation by local visitors after 1995 . Prior to this period the demand for accommodation exceeded the supply. This was especially true for the December, April, July and October school holidays. During the July holiday period, for example, the demand was 5 times greater than the supply. It was hypothesised that costs or pricing factors may be one of the reasons for the decline in the demand for accommodation. After discussions with senior members of the Park's management team, the need to conduct a price sensitivity study became apparent. During the quantitative research phase a survey was conducted with the aid of a questionnaire (Afrikaans and English) in which respondents were requested to participate in a pair-wise trade-off conjoint analysis in which a real purchase situation was simulated. This was done because conjoint analysis is generally regarded as the most used category of price sensitivity measurement methods. The Conjoint Value Analysis (CVA), Version 2.0 computer programme was used for this study. One of the primary objectives of the study was to measure the consumer preferences of tourists by making trade-offs between attributes at various levels, enabling them to make complex decisions not only on one factor but on several factors "jointly".

The conjoint experiment was designed according to the guidelines offered by Hair et al (1998: 564-581). The survey was conducted in six camps of the Kruger National Park among 428 respondents in the late nineties. The respondents were requested to indicate their preferences by ranking a number of different combinations of attribute levels on a nine-point Likert scale. The following were some of the findings of the study:

- Overall, the respondents were satisfied with the quality of accommodation in the Park.

- They were not satisfied with the general price level for accommodation, and specifically the prices of meals in restaurants and goods sold in the shops.

- As expected, the majority of the respondents preferred the more luxurious type of accommodation (cottage, hut with private ablution) to the less luxurious type of accommodation.

Burger and Herbst (2002) used a conjoint approach to determine the importance of certain clothing attributes, such as style, price, brand and outlet choice during the decision-making process of teenagers when purchasing denims. Teachers from two Afrikaans and two English schools in the Pretoria region acted as interviewers, and presented 213 (13-16 years) secondary school pupils with 25 hypothetical paired-wise product profiles. The results indicated, inter alia, that the brand name (for example Levi or Diesel) is the most important attribute teenagers consider before making a purchase. Diesel was the most popular brand, followed by Calvin Klein.

South Africa has never been a major player in the pearl industry. For many years now South African pearl distributors have travelled to the East to purchase oyster pearls and mabès, which they import to South Africa. Many consumers might also have a perception that quality pearls come from the East (Hamman \& Kotze, 2001). Pearl dealers need to determine whether consumers would prefer to purchase the raw product or a pearl that has been set in precious metal. These and other questions prompted the management of Hermanus Abalone (Pty) Ltd and other pearl dealers to test local consumers' perceptions with respect to these and other relevant issues (Hamman \& Kotze, 2001). A conjoint study was executed to determine, inter alia, the following: the tradeoffs consumers make between factors such as colour and size while considering purchasing abalone mabè pearls, the extent to which the country of origin has an influence on consumers' perception of quality, consumers' preferred place of purchase, and whether consumers would prefer mabès in settings to the raw product. Using the method of non-probability sampling, the researcher took a convenience sample by questioning 100 female respondents (18-65 years old). The attributes and levels used in the study included the following: type of mabè, colour, country of origin and price. The results of the study indicated, inter alia, the following:

- The respondents preferred the Oyster Mabè to the Abalone Mabè.

- They preferred white to blue or pink as a colour.

- As could be expected, South Africa ranked first when asked to nominate the country of preference.

- Overall, the colour attribute was ranked the highest with the country of origin in second place. 
Conjoint analysis is closely related to traditional experimentation. The conjoint technique developed from the need to analyse the effects of the factors we control that are often qualitatively specified or weakly measured. Conjoint analysis is actually a family of techniques and methods, all theoretically based on the models of information integration and functional measurement (Hair et al, 1998:388). Utility is a subjective judgement of preference unique to each individual. It is the conceptual basis for measuring value in conjoint analysis. It is a measure of overall preference because it encompasses all product or service features, both tangible and intangible. Utility is assumed to be based on the value placed on each of the levels of the attributes and expressed in a relationship reflecting the manner in which the utility is formulated for any combination of attributes (Hair et al, 1998:392).

\section{KEY DECISIONS OR STEPS WHEN DESIGNING A CONJOINT VALUE ANALYSIS}

There are many different conjoint methods. The researcher should weigh each research situation and pick the right combination of tools for the project. Sudman and Blair (1998:235) distinguish between an arrangement that uses all possible combinations of features ("full factorial design") and one that uses only some of the combinations ("fractional design"). A general rule of thumb, according to these authors, is to limit the descriptions to no more than 30. Full-profile conjoint value analysis (CVA) is useful for measuring up to about six attributes (Hair et al, 1998:401). CVA is designed for paper and pencil study, but can be computerised by means of the $\mathrm{Ci} 3$ System for computer interviewing. CVA calculates a set of utilities for each individual, using traditional full-profile card-sort (either rating or ranked) or pair-wise ratings. CVA can attach prices to each attribute level to measure price sensitivities for individual features. This is realistic for modelling categories in which buyers actually see the prices for each component of the product, such as with restaurant meals, cellular phones and packages (Omre, 2000:4). If the full-profile approach is used, it is important to limit the number of attributes and levels, increase the number of profiles, or use more parsimonious models (such as the vector or ideal point models) so as to increase the degrees of freedom for conjoint estimation (Green \& Srinivasan, 1990).

Hair et al (1998:400-436) provide a comprehensive description of the design of a conjoint analysis experiment (see Figure 2). The Hair model consists of seven phases, which include 14 steps. Figure 1 highlights the more critical decision points in a conjoint experiment, according to Churchill and lacobucci (2002:753).

For the purposes of this article, a brief summary of each of the above-mentioned steps follows.

Select attributes The attributes used will stem primarily from the objectives of the study. The researcher should be guided by the principle that the attributes should be both capable of being acted on and important to consumers. These attributes are those that the company can do something about; "... that is, it has the technology to make changes that might be indicated by consumer preferences" (Churchill \& lacobucci, 2002:754).

Determine attribute levels The number of levels for each attribute has a direct bearing on the number of stimuli respondents will be asked to judge. The more there are, the heavier the burden that is placed on the consumer. Churchill and lacobucci (2002:754) suggest that the researcher make the range for the various attributes somewhat larger than the range normally found but not so large as to make the options unbelievable.

Determine attribute combinations This will determine what the full set of stimuli will look like. One cannot expect a respondent to provide meaningful judgments if there are five attributes and three levels $(3 \times 3 \times 3 \times 3 \times 3=243)$ each of rank-order judgments.

Select form of presentation of stimuli and nature of judgments Basically, three approaches can be used, namely: verbal description, paragraph description, and pictorial representation. When visual aids are used they are normally used in combination with verbal descriptions. The nature of the judgments that must be secured from the respondents is related to the form of presentation. One method is to ask them to rank the alternatives according to preference or intention to buy. Rating scales have recently become more popular, however.

Decide on aggregation of judgments This step basically involves the decision whether the responses from consumers or groups of consumers will be aggregated and, if so, how this will be done? If groups are formed, operationally this means estimating the utilities for the individual-level models and then clustering them into homogeneous groups. According to Churchill and lacobucci (2002:759), this highlights an attractive feature of conjoint analysis because it allows market share predictions for selected product alternatives.

Select analysis technique The final step in the design of a conjoint analysis project is to select the technique that will be used to analyse the data. The choice depends largely on the method that was used to secure the input judgments by the respondents. For example, when rank-order data have been obtained, the assumption of a linear relationship may be dubious, so a non-metric regression model may be substituted to estimate the utilities (Churchill \& lacobucci, 2002:759).

\section{CONCLUSION}

Multiple discriminant analysis helps to understand and explain research problems that involve a single cate- 


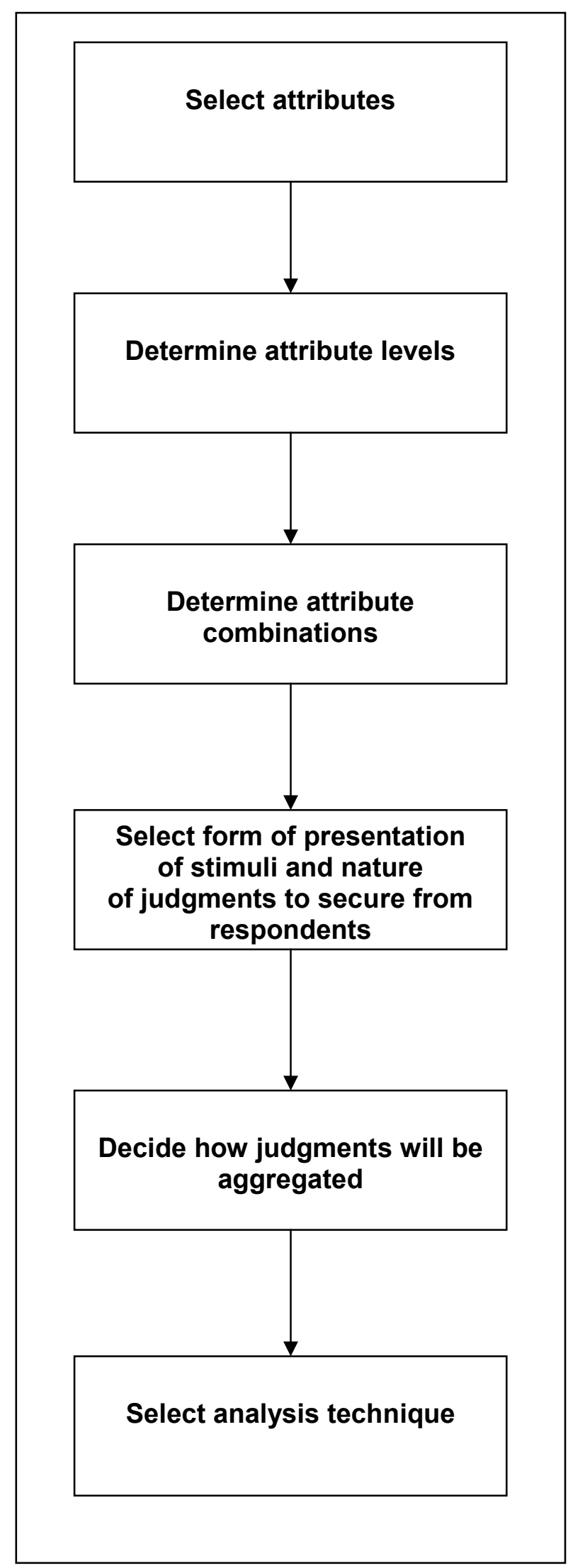

Figure 1: Designing a conjoint analysis experiment: Stages of the conjoint analysis decision diagram (Adapted from Churchill \& lacobucci, 2002 753) gorical dependent variable and several metric independent variables. A mixed data set is also possible for the independent variables if the non-metric variables are coded (Hair et al, 1998:321). According to Hair et al (1998:436) conjoint analysis places more emphasis on the ability of the researcher or manager to theorise about the behaviour of choice than it does on analytical techniques. Thus it should be viewed primarily as exploratory, because many of its results are directly attributable to basic assumptions made during the course of the design and the execution of the study. The critical interplay between the assumed conceptual model of decision-making and the appropriate elements of the conjoint analysis makes this a unique multivariate method (Hair et al, 1998:436).

It is of critical importance for the researcher to be comfortable with the various research techniques, for it is only once he or she fully comprehends the research method that the research can be expanded to become meaningful. As we are in a period of farreaching change, where information abounds, organisations recognise the increasing value of making strategic and tactical decisions based on solid research. By conducting a conjoint study the researcher could determine consumer preferences and also expand her or his knowledge to gain an understanding of new emerging techniques as well as older foundational ones. This will ensure solid usable research.

\section{REFERENCES}

BEARDEN, W, INGRAM, T \& LaFORGE, R. 2001. Marketing Principles and Perspectives. $3^{\text {rd }}$ Ed. Boston. McGraw Hill.

BURNS, A \& BUSH, R. 1998. Marketing Research. $2^{\text {nd }}$ Ed. London. Prentice-Hall.

COOPER, D \& SCHINDLER, P. 1998. Business Research Methods. $6^{\text {th }}$ Ed. Boston. McGraw Hill.

BURGER, C \& HERBST, F. 2002. Research Paper. University of Pretoria.

CHURCHILL, G \& IACOBUCCI, D. 2002. Marketing Research, Methodoligal Foundations. $8^{\text {th }}$ Ed. London. Harcourt Publishing.

DANE, F. 1990. Research Methods. Pacific Grove. Wadsworth.

DE VOS, R. 2002. Research Paper. University of Pretoria.

GREEN, PE \& SRINIVASAN, V. 1990. Conjoint Analysis in Marketing: New Developments with Implications for Research and Practice. Journal of Marketing 54 (October):3-19.

GREEN, PE \& SRINIVASAN, V. 1978. Conjoint Analysis in Consumer Research: Issues and Outlook. Journal of Marketing 55 (September):103-123.

HAIR, JF, ANDERSON, RE, TATHAM, RL \& BLACK, WC. 1998. Multivariate Data Analysis. $5^{\text {th }}$ Ed. Upper Saddle River, New Jersey. Prentice-Hall International. HAMMAN, M \& KOTZE, T. 2001 Paper. University of Pretoria.

KOTLER, P. 2000. Marketing Management. The Millennium Edition. London. Prentice-Hall.

LANG, J \& CROWN, E. 1993. Country-of-origin ef- 


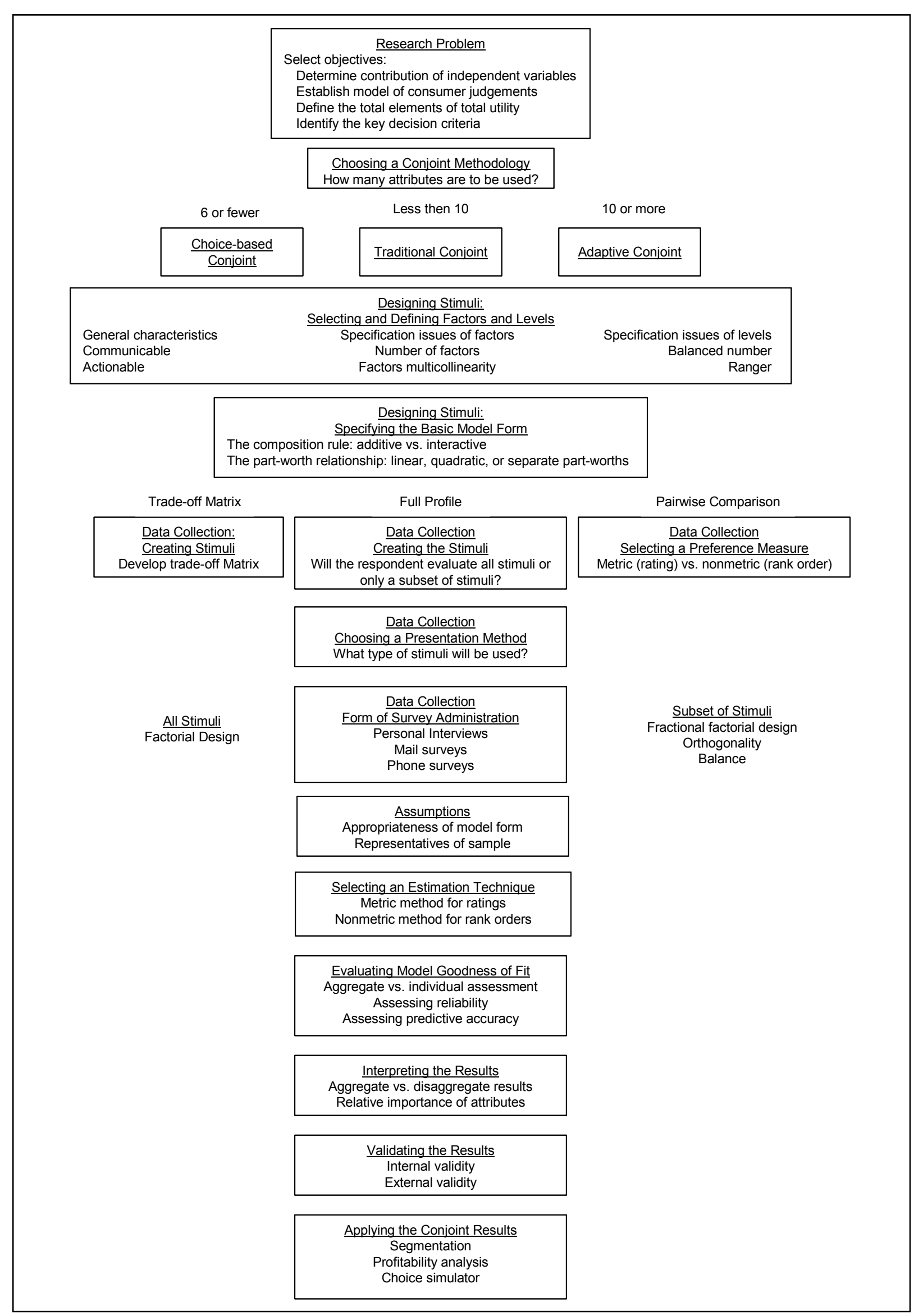

Figure 2:

Key decisions when conducting a conjoint analysis (Hair et al, 1998:401-419) 
fect in apparel choices: A conjoint analysis. Journal of Consumer Studies and Home Economics 17(6):8798.

LOUVIERE, JJ. 1988. Analyzing Decision Making. Metric Conjoint Analysis. London. Sage Publishers. MARKET DECISIONS CORPORATION. 1996. Conjoint Analysis. http://sba.cerf.net/mdc.

OMRE, B. 2000. Which Conjoint Method should I use? Sawtooths Software.

OPPEWAL, H \& VRIENS, M. 2000. Measuring perceived service quality using integrated conjoint experiments. The International Journal of Bank Marketing 18(4):154-169.

PETER, J \& DONNELLY, J. 2001. Marketing Management. $6^{\text {th }}$ Ed. Boston. McGraw Hill.
RUTTER, N \& EDWARDS, O. 1999. Ready to ware. Forbes 163(7): 30-33.

SUDMAN, S \& BLAIR, E. 1998. Marketing Research. Boston. McGraw Hill.

SCHUTTE, I. 1999. The role of price sensitivity and pricing in the demand for accommodation of local visitors to the Kruger National Park. Unpublished MCom Thesis. University of Pretoria.

SHETH, JN, \& SISODIA, R. 1999. Revisiting Marketing's Lawlike Generalizations. Journal of the Academy of Marketing Science 27(1): 71-87.

WYNER, G. 1995. Trade-off techniques and marketing issues.

Marketing Research: A Magazine of Management and Applications 7(4): 32-43. 